\title{
ОГЛЯД СТАНУ КНИГОВИДАННЯ \\ ТА КНИГОРОЗПОВСЮДЖЕННЯ ЗА ЧАСІВ НЕЗАЛЕЖНОӦ УКРАЇНИ
}

За 20 років існування незалежної України було зроблено чимало спроб розвинути видавничу справу, а точніше книговидання та книгорозповсюдження на території нашої держави. 1 серпня 1992 року - Постанова Кабінету Міністрів України 3 питань Державного комітету України по пресі, в якій передбачалося, що «Держкомпреси реалізує державну політику у сфері видавничої справи в усіх ï̈ видах і формах, координує діяльність підприємств і організацій галузі та забезпечує державну підтримку у вирішенні ними завдань щодо задоволення потреб населення і суспільного виробництва» [1]. Проте постанова втратила чинність на підставі Постанови КМ від 22 листопада 1993 року з питань Державного комітету України у справах видавництв, поліграфії та книгорозповсюдження. Саме ця Постанова стала наріжним каменем на шляху розвитку книговидання в Україні. Згідно з Постановою «Держкомвидав реалізує державну політику у сфері видавничої справи, поліграфії та книгорозповсюдження, розробляє та здійснює заходи щодо розвитку матеріально-технічної бази друкованих засобів масової інформації та книговидання» [2]. Ще у першій Постанові КМ від 1 серпня 1992 року були визначені головні завдання:

- проведення у життя законів України, інших державних нормативних актів 3 метою сприяння засобами книгови- дання і періодичної преси, відродження і розвитку духовної культури України, її економіки, науки, освіти;

- державне регулювання, організація, координація видавничої справи, стимулювання іï розвитку з метою задоволення духовних, культурних, освітніх, професійних, національних, політичних, соціальних, правових потреб народу України;

- заснування у встановленому порядку державних видавництв, підприємств, визначення мети їх діяльності;

- формування і розміщення державного замовлення;

- розробка та обґрунтування проектів цільових державних програм;

- забезпечення єдиного підходу до економічних та технічних вимог і стандартів на продукцію (роботи, послуги);

- послідовне впровадження у видавничу справу прогресивних форм ринкових відносин і структур, здійснення активної науково-технічної політики, підвищення ролі галузевої науки, підтримка творчої, господарської ініціативи та підприємництва;

- здійснення заходів щодо розвитку державної бібліографії творів друку, ведення державної бібліографічної статистики з розробкою аналітичних наукових і довідково-інформаційних матеріалів;

- збереження й постійне поповнення Державного архіву 
друку 3 використанням його фондів для збагачення духовної культури України;

- забезпечення державного захисту книговидання і періодичної преси України, протидія монопольним і протиправним тенденціям, іншим негативним явищам, які завдають шкоди інтересам споживачів друкованих видань;

- соціальний захист працівників книговидання і періодичної преси [1].

На той час ці завдання виконував Держкомпреси, проте 3 наступною Постановою вони перейшли до іншого центрального органу державної виконавчої влади - Держкомвидаву. У формулювання завдань були внесені деякі якісні зміни, наприклад:

- здійснення заходів щодо поліпшення якості та конкурентоспроможності друкованої продукції України;

- сприяння національної школи художнього оформлення і конструювання видань, книжкового дизайну, мистецтва книги;

- розвиток міжнародного співробітництва у галузі видавничої справи та книгообміну [2].

Проте і ця постанова втратила чинність на підставі постанови КМ від 1 грудня 1994 року на виконання Указу Президента України від 18 листопада 1994 року № 689/94 «Про утворення Міністерства України у справах преси та інформації» [3].

У 2007 році авторський колектив на чолі з О. Гриценком створили аналітичний огляд, в якому розглядали розвиток книговидавничої справи й книжкового ринку в Україні за роки незалежності. Було виокремлено чотири основні періоди:

- 1990-1995: повільний спад, викликаний, на погляд багатьох, болісною трансформацією державної планової економіки видавничої галузі, а також загальною економічною кризою в країні, який супроводжувався, водночас, урізноманітненням ринкової пропозиції;

- 1996-1999: період більш різких і драматичних змін, спричинених, по-перше, спробами запровадження протекціоністичних заходів у галузі, по-друге, масштабною фінансовою кризою 1998 року;

- 1999-2002: період поступової стабілізації при постійному зростанні вітчизняної книжкової пропозиції за назвами (в українському книговиданні в цей період уже домінує приватний сектор);

- приблизно - 2003 - повільне зростання книговидавничої індустрії, що стимулюється загальним зростанням української економіки, а також запровадженими в цей час податковими пільгами для видавничої галузі [4].

Взявши до розгляду доступні статистичні данні, можна простежити певні тенденційні зміни - ситуація з книговиданням в Україні й досі не зовсім певна, проте 28 липня 2011 року відбулося I засідання Міжвідомчої комісії з питань сприяння розвитку вітчизняного книговидання та книгорозповсюдження, на якому члени цієї комісії на чолі з головою комісії - міністром освіти України Дмитром Табач- 
ником вирішували питання нагальної важливості стосовно книговидання в Україні. За статистикою Державної наукової установи «Книжкова палата України імені Івана Федорова», відбувається падіння за останні роки кількості видань на одного мешканця України, за цими даними 2008 рік вважається найкращим за останні 15 років, хоча й тоді ця цифра сягнула лише 1,26 книги на душу населення. Для порівняння 1990 року видавалося 3,2 книга на душу населення; $1992-2,6$; $1995-1,33$; найменша кількість 1999 року 0,36 книг на одного мешканця України, у 2010 - 1 книга на душу населення. У 2010 році у Книжковій палаті України було зареєстровано 22557 назв книг і брошур загальним тиражем 45058,3 тис. примірників, що порівняно з даними 2009 року становить майже на відсоток більше за назвами та на 7,1 \% менша за тиражами.

На засіданні міжвідомчої комісії Голова Держкомтелерадіо України Олександр Курдінович заявив: «2011 рік - рік перелому, а 2012 рік - рік нових показників розвитку галузі».

Лишається сподіватись, що 1 книга на душу населення - це не брак знань, втрачених за 20 років, а показник перехідного етапу до кращих часів існування незалежної української книги.

1. Електронний ресурс. - Режим доступу : http://zakon.rada.gov.ua/cgibin/laws/main.cgi?nreg=443-92-\%EF. 2. Електронний ресурс. - Режим доступу : http://zakon.rada.gov.ua/cgi-bin/laws/main.cgi?nreg=944-93-\%EF. 3. Електронний ресурс. - Режим доступу : http://zakon.rada.gov.ua/cgibin/laws/main.cgi?nreg=803-94-\%EF. 4. Електронний ресурс. - Режим доступу : http://www.culturalstudies.in.ua/2007_analiz_5_1.php.

Катерина Козій, студентка 2-го курсу, ВПІ НТУУ «КПІ» 